CRYSTALLOGRAPHIC COMMUNICATIONS

ISSN 2056-9890

Received 24 June 2016

Accepted 12 August 2016

Edited by M. Weil, Vienna University of

Technology, Austria

Keywords: crystal structure; pyroborates; interplanar angle; layered framework; bond-valencesum calculations.

CCDC reference: 1499124

Supporting information: this article has supporting information at journals.iucr.org/e

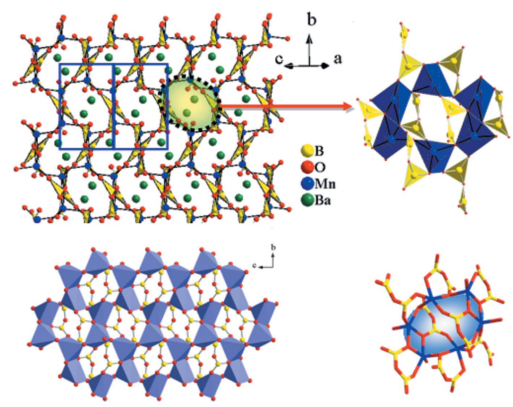

OPEN $\odot$ ACCESS

\section{Crystal structure of $\mathrm{BaMnB}_{2} \mathrm{O}_{5}$ containing structurally isolated manganese oxide sheets}

\author{
Elizabeth M. Maschmeyer, ${ }^{a}$ Liurukara D. Sanjeewa ${ }^{b}$ and Kulugammana G. S. \\ Ranmohotti $^{\mathrm{a} *}$
}

\begin{abstract}
${ }^{a}$ Division of Chemistry and Biological Sciences, Governors State University, 1 University Parkway, University Park, IL 60484-0975, USA, and ${ }^{\mathbf{b}}$ Department of Chemistry, Clemson University, Clemson, SC 29634-0973, USA. *Correspondence e-mail: kranmohotti@govst.edu
\end{abstract}

In an attempt to search for mixed alkaline-earth and transition metal pyroborates, the title compound, barium manganese(II) pyroborate, has been synthesized by employing a flux method. The structure of $\mathrm{BaMnB}_{2} \mathrm{O}_{5}$ is composed of $\mathrm{MnO}_{5}$ square pyramids that form $\mathrm{Mn}_{2} \mathrm{O}_{8}$ dimers by edge-sharing and of pyroborate units $\left(\left[\mathrm{B}_{2} \mathrm{O}_{5}\right]^{4-}\right)$ that are composed of two corner-sharing trigonal-planar $\mathrm{BO}_{3}$ units. These building blocks share corners to form ${ }_{\infty}^{2}\left[\mathrm{MnB}_{2} \mathrm{O}_{5}\right]^{2-}$ layers extending parallel to (100). The $\mathrm{Ba}^{2+}$ cations reside in the gap between two manganese pyroborate slabs with a coordination number of nine. The title compound forms an interesting spiral framework propagating along the $2_{1}$ screw axis. The structure is characterized by two alternating layers, which is relatively rare among known transition-metal-based pyroborate compounds.

\section{Chemical context}

Numerous borates with various crystal structures and compositions have been widely investigated over the last few decades (Heller et al., 1986). Pyroborates containing the $\left(\mathrm{B}_{2} \mathrm{O}_{5}\right)^{4-}$ anion were first structurally characterized in 1950 (Berger, 1950). Pyroborates can be divided into two subclasses such as alkaline-earth-based pyroborates with general formula $A_{2} \mathrm{~B}_{2} \mathrm{O}_{5}(A=$ alkaline earth metal $)$ and transition-metal-based pyroborates with general formula $M M^{\prime} \mathrm{B}_{2} \mathrm{O}_{5}$. If $M=M^{\prime}$, the pyroborate is considered to be homo-metallic, otherwise it is hetero-metallic.

Alkaline-earth-based pyroborates adopt different structure types. During the investigation of the $\mathrm{BaO} / \mathrm{B}_{2} \mathrm{O}_{3}$ system, Hubner revealed $\mathrm{Ba}_{2} \mathrm{~B}_{2} \mathrm{O}_{5}$ crystallizing in space group $P 2 / m$ (Hubner, 1969). The other alkaline-earth-based $A_{2} \mathrm{~B}_{2} \mathrm{O}_{5}$ pyroborates $(A=\mathrm{Mg}, \mathrm{Ca}, \mathrm{Sr})$ have been synthesized by hightemperature solid-state reactions. $\mathrm{Mg}_{2} \mathrm{~B}_{2} \mathrm{O}_{5}$ (Guo et al., 1995b) crystallizes in space group $P 2_{1} / c$. $\mathrm{Ca}_{2} \mathrm{~B}_{2} \mathrm{O}_{5}$ (Lin et al., 1999a) and $\mathrm{Sr}_{2} \mathrm{~B}_{2} \mathrm{O}_{5}$ (Lin et al., 1999b) are isotypic and crystallize in the same space group type as $\mathrm{Mg}_{2} \mathrm{~B}_{2} \mathrm{O}_{5}$ but have a different structure from the latter. Additionally, there exists a triclinic magnesium pyroborate ( $P \overline{1}$; Guo et al., 1995a). The existence of mixed alkaline-earth-based pyroborates $\left(A A^{\prime} \mathrm{B}_{2} \mathrm{O}_{5}\right)$ has been proven by the study of naturally occurring minerals. The crystal structures of two polymorphs of $\mathrm{CaMgB}_{2} \mathrm{O}_{5}$, kurchatovite and clinokurchatovite, have been originally determined in space group types $P c 2_{1} b$ (Yakubovich et al., 1976) and $P 2_{1} / c$ (Simonov et al., 1980). However, the crystal structures of both minerals have been re-examined and refined in different space 


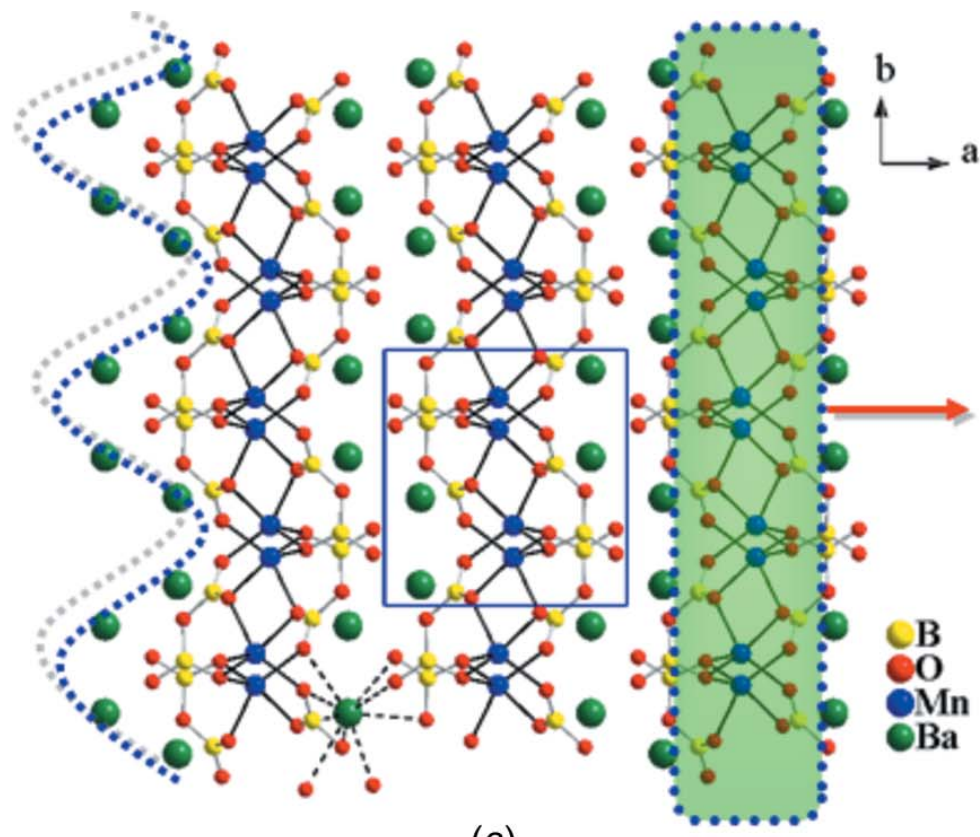

(a)

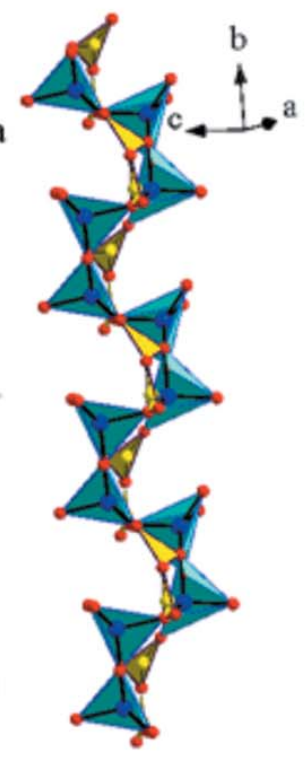

(b)

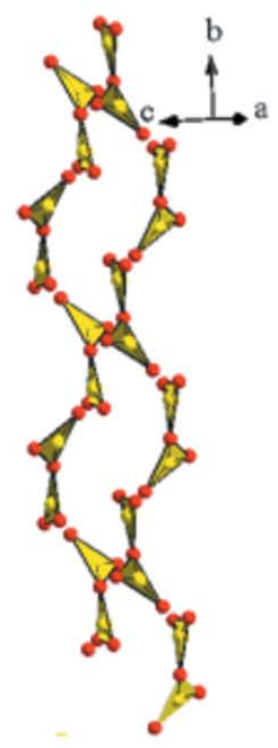

(c)

Figure 1

(a) Perspective view of the structure of $\mathrm{BaMnB}_{2} \mathrm{O}_{5}$ viewed along the $c$ axis. The wavy and dotted line (left) indicates the zigzag arrays of $\mathrm{Ba}$ atoms. Only one $\mathrm{Ba}$ atom with bonds is drawn for clarity, demonstrating the function of $\mathrm{Ba}-\mathrm{O}$ bonds with regard to holding neighboring $\left[\mathrm{MnB}_{2} \mathrm{O}_{5}\right]^{2-}$ slabs. $(b)$ Polyhedral representation showing the ${ }_{\infty}^{2}\left[\mathrm{MnB}_{2} \mathrm{O}_{5}\right]^{2-}$ spiral framework centered around the $2_{1}$ screw axis of the unit cell. (c) Polyhedral representation showing the arrangement of isolated pyroborate units viewed approximately along the [101] direction.

group types (Callegari et al., 2003). Based on these models, kurchatovite crystallizes in space group type $P b c a$ whilst clinokurchatovite crystallizes in space group type $P 2_{1} / c$.

Investigations of transition-metal-based homo-metallic pyroborates, $M_{2} \mathrm{~B}_{2} \mathrm{O}_{5}$ have led to four compounds, namely $\mathrm{Mn}_{2} \mathrm{~B}_{2} \mathrm{O}_{5}$ (Sarrat et al., 2005), $\mathrm{Co}_{2} \mathrm{~B}_{2} \mathrm{O}_{5}$ (Rowsell et al., 2003), $\mathrm{Cd}_{2} \mathrm{~B}_{2} \mathrm{O}_{5}$ (Weil, 2003), and $\mathrm{Fe}_{2} \mathrm{~B}_{2} \mathrm{O}_{5}$ (Neumair \& Huppertz, 2009). These phases crystallize isotypically with the triclinic form of $\mathrm{Mg}_{2} \mathrm{~B}_{2} \mathrm{O}_{5}$ (Guo et al., 1995a). Efforts have been made to isolate transition-metal-based hetero-metallic phases, $M M^{\prime} \mathrm{B}_{2} \mathrm{O}_{5}$. This has resulted in the synthesis of $\mathrm{MnCoB}_{2} \mathrm{O}_{5}$ and $\mathrm{MnMgB}_{2} \mathrm{O}_{5}$ (Utzolino \& Bluhm, 1996), and $\mathrm{Ni}_{1.5} \mathrm{Zn}_{0.5} \mathrm{~B}_{2} \mathrm{O}_{5}$ and $\mathrm{Co}_{1.5} \mathrm{Zn}_{0.5} \mathrm{~B}_{2} \mathrm{O}_{5}$ (Busche \& Bluhm, 1995). These structures are also isotypic with the triclinic form of $\mathrm{Mg}_{2} \mathrm{~B}_{2} \mathrm{O}_{5}$.

Investigations of the $\mathrm{BaO} / \mathrm{CuO} / \mathrm{B}_{2} \mathrm{O}_{3}$ phase diagram has resulted in the isolation of a non-centrosymmetric pyroborate, $\mathrm{BaCuB}_{2} \mathrm{O}_{5}$ (Smith \& Keszler, 1997) with a unique structure type in space group type $C 2$. As part of an effort to isolate new mixed alkaline earth and transition metal pyroborates, we have investigated the $\mathrm{BaO} / \mathrm{MnO} / \mathrm{B}_{2} \mathrm{O}_{3}$ phase diagram. In this study, we have grown single crystals of $\mathrm{BaMnB}_{2} \mathrm{O}_{5}$ and analyzed its crystal structure.

\section{Structural commentary}

The crystal structure of $\mathrm{BaMnB}_{2} \mathrm{O}_{5}$ defines a new structure type that can be described as being composed of manganese pyroborate slabs with composition ${ }_{\infty}^{2}\left[\mathrm{MnB}_{2} \mathrm{O}_{5}\right]^{2-}$ that extend parallel to (100). Fig. $1 a$ shows a perspective drawing of the $\mathrm{BaMnB}_{2} \mathrm{O}_{5}$ structure with the quasi-two-dimensional lattice characterized by $\left[\mathrm{MnB}_{2} \mathrm{O}_{5}\right]^{2-}$ slabs. The barium cations reside between the parallel slabs and maintain the interslab connectivity through coordination to nine oxygen atoms (Fig. 2c).

Two non-equivalent boron atoms are present in the structure; both are surrounded by three oxygen atoms to form almost regular trigonal-planar units. As depicted in Fig. $2 b$, the isolated $\left[\mathrm{B}_{2} \mathrm{O}_{5}\right]^{4-}$ pyroborate groups are composed of two corner-sharing trigonal-planar $\mathrm{BO}_{3}$ units. In the reported pyroborate structures (Thompson et al., 1991), the terminal $\mathrm{BO}_{2}$ planes pivot about the torsion angles to afford deviations from coplanarity that can range from 0 to $76.8^{\circ}$ where the $\mathrm{B}-$ $\mathrm{O}-\mathrm{B}$ angle ranges from 112 to $180^{\circ}$. In $\mathrm{BaMnB}_{2} \mathrm{O}_{5}$, the pyroborate groups show closely related geometric features as previously noted (Thompson et al., 1991), exhibiting a B-O$\mathrm{B}$ angle of $125.1(5)^{\circ}$ whilst the dihedral angle between the two $\mathrm{BO}_{3}$ units within the pyroborate group is $48.62(8)^{\circ}$. The

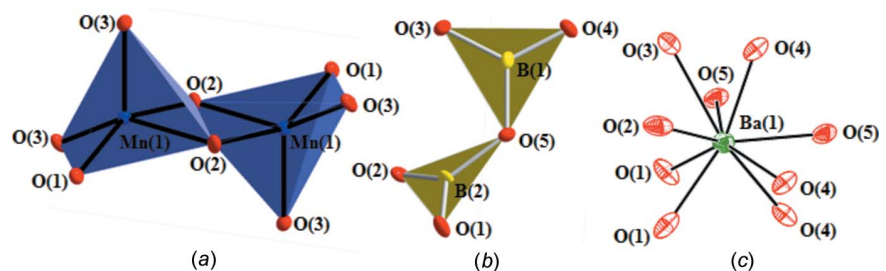

Figure 2

(c)

(a) Partial structure showing $\mathrm{Mn}_{2} \mathrm{O}_{8}$ dimers (polyhedral drawing). The apical oxygen, O3, in each $\mathrm{MnO}_{5}$ square pyramid points in opposite directions. (b) Corner-sharing $\mathrm{BO}_{3}$ groups forming a pyroborate unit. The $\mathrm{BO}_{3}$ units within the pyroborate group are linked through a common $\mathrm{O}$ atom, O5. (c) The barium cation resides in a $\mathrm{BaO}_{9}$ environment. Anisotropic displacement parameters are drawn at $95 \%$ probability. 


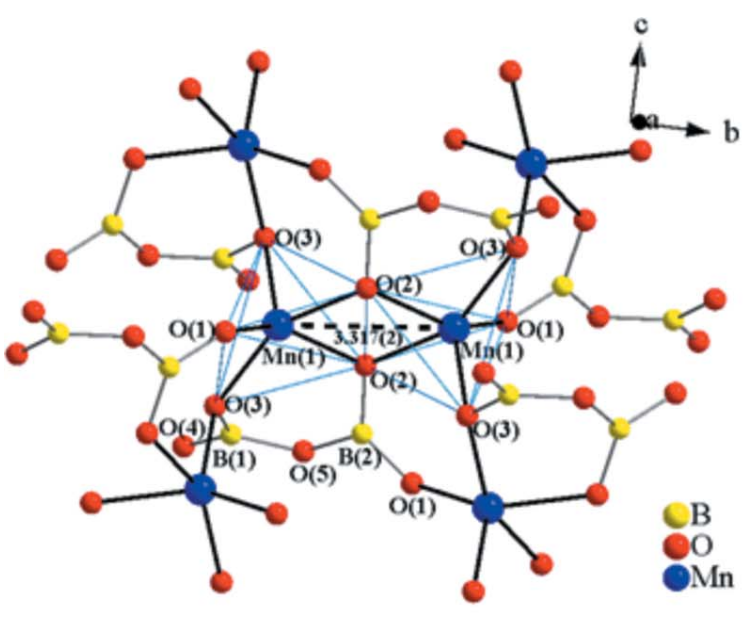

(a)

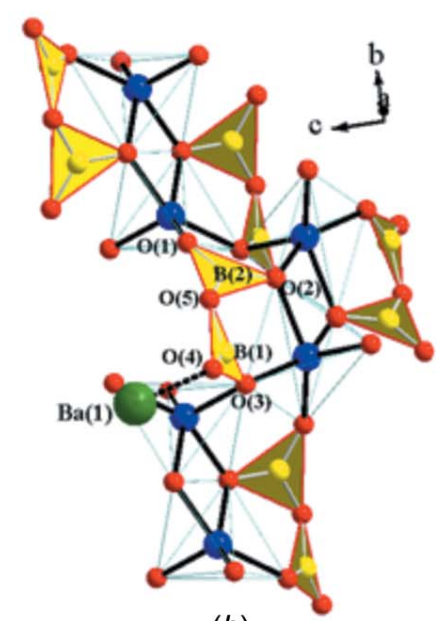

(b)

Figure 3

(a) The $\mathrm{Mn} 1 \mathrm{O}_{5}$ square pyramids (ball and stick drawing) share a common edge, $\mathrm{O} 2-\mathrm{O} 2$, forming an $\mathrm{Mn}_{2} \mathrm{O}_{8}$ unit. (b) The $\mathrm{B} 2 \mathrm{O}_{3}$ unit (polyhedral drawing), shares two corners with neighboring $\mathrm{MnO}_{5}$ square pyramids (ball and stick drawing) through $\mathrm{O} 1$ and $\mathrm{O} 2$. The only unshared oxygen, $\mathrm{O} 4$, of the pyroborate group forms a bond with a Ba atom.

(a)

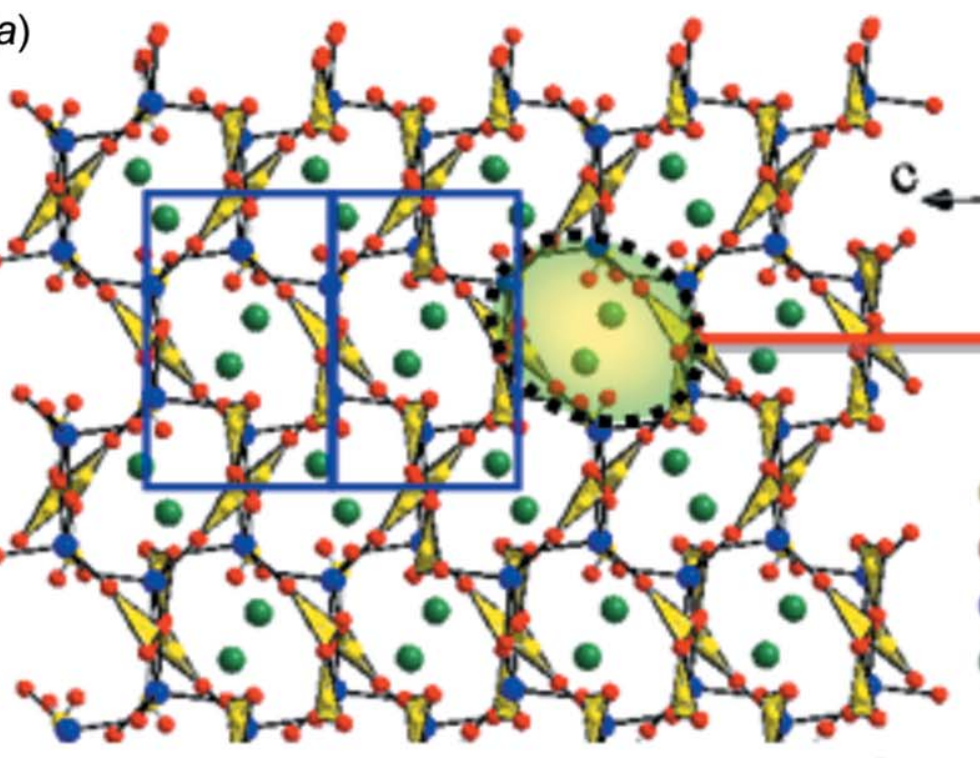

(b)

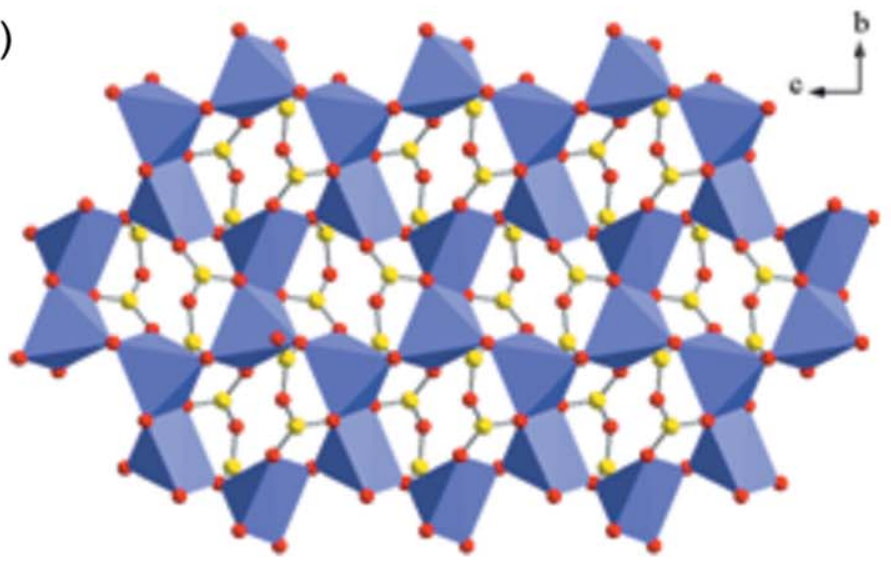

(c)

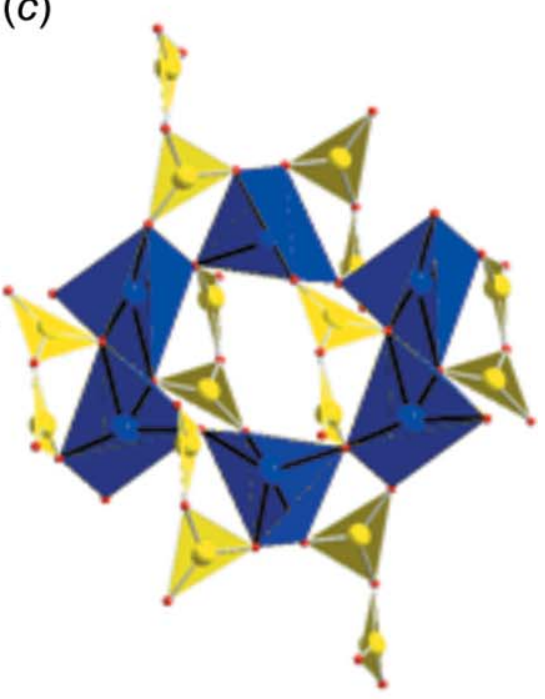

(d)

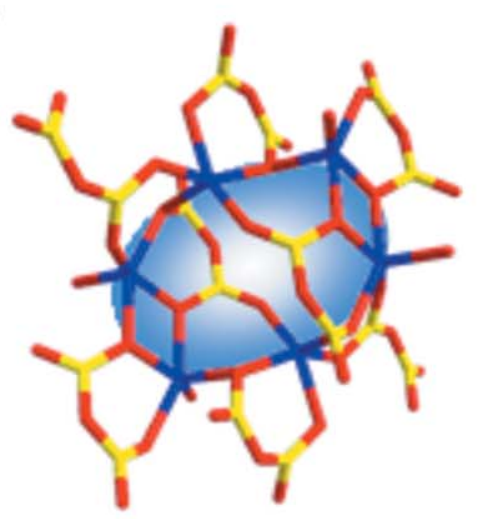

Figure 4

(a) Extended structure of $\mathrm{BaMnB}_{2} \mathrm{O}_{5}$ viewed approximately along the [101] direction. The connectivity of the barium atoms is not shown for clarity. (b) Partial structure of $\left[\mathrm{MnB}_{2} \mathrm{O}_{5}\right]^{2-}$ slab viewed along [100] where the polyhedral drawing represents $\mathrm{MnO}_{5}$ square pyramids and $\mathrm{B}_{2} \mathrm{O}_{5}$ units are represented by ball-and-stick drawing. (c) Edge-sharing and corner-sharing $\mathrm{MnO}_{5}$ units corner-share with $\mathrm{B}_{2} \mathrm{O}_{5}$ pyroborate groups (polyhedral drawing) to create a cage. (d) Stick drawing of one cage with empty space in the middle. 


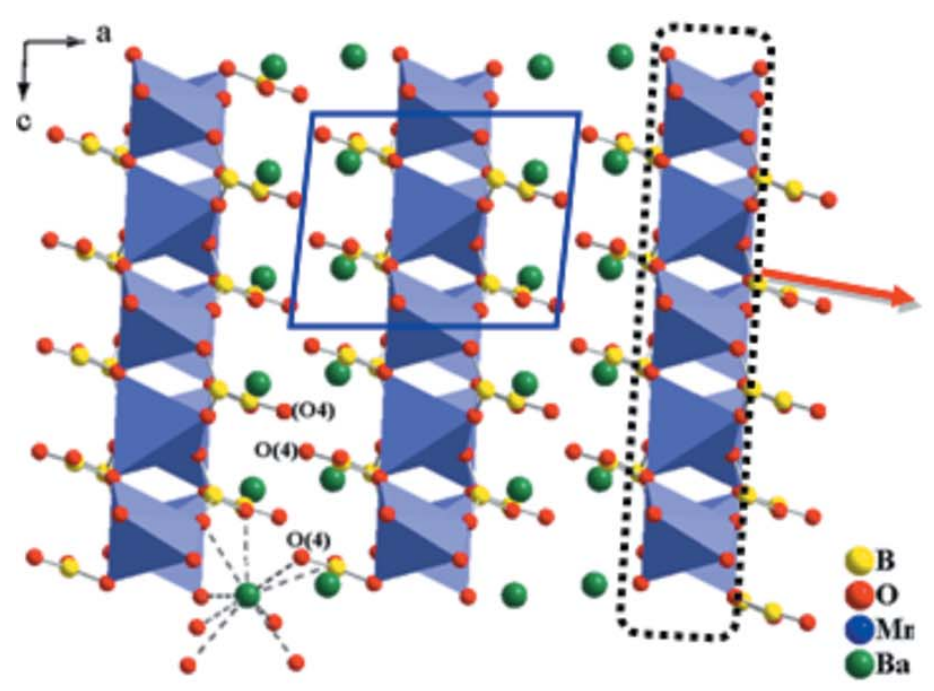

(a)

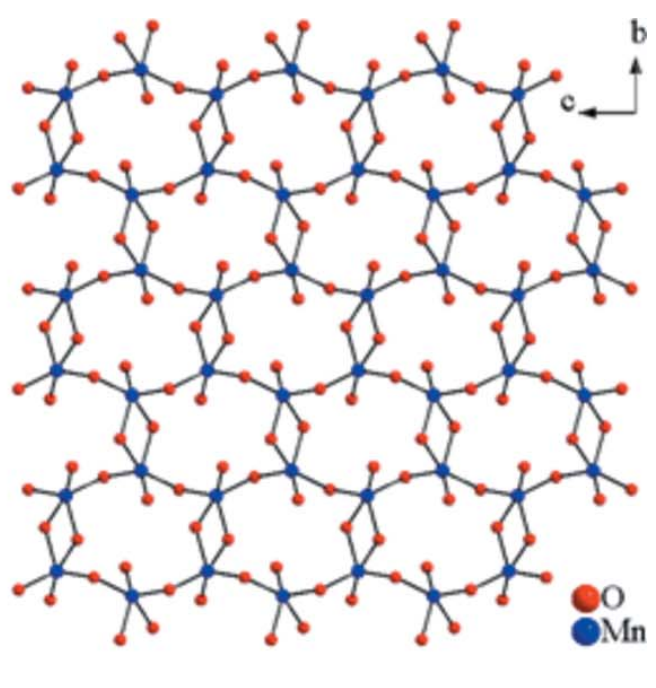

(b)

Figure 5

(a) Layered $\mathrm{BaMnB}_{2} \mathrm{O}_{5}$ shown by polyhedral and ball-and-stick drawing viewed along the [010] direction. (b) Ball-and-stick drawing of a portion of the manganese oxide network formed by interconnected $\mathrm{Mn}_{2} \mathrm{O}_{8}$ dimers by corner sharing.

asymmetry of the bond lengths in the $\mathrm{B}_{2} \mathrm{O}_{5}$ group is indicated by slightly varied bond lengths of terminal and bridging $\mathrm{B}-\mathrm{O}$ bonds. The bridging $\mathrm{B}-\mathrm{O}$ bond lengths are slightly longer [B1-O5: 1.423 (7); B2-O5: 1.432 (7) A] than the terminal $\mathrm{B}-\mathrm{O}$ bond lengths [range $1.332(8)-1.384(7) \AA$ ] . Notwithstanding, the average $\mathrm{B}-\mathrm{O}$ bond length $(1.380 \AA)$ in the title compound is very close to the corresponding average $\mathrm{B}-\mathrm{O}$ bond length in $\mathrm{BO}_{3}$ groups in previously reported borates (1.370 А; Zobetz, 1982). Fig. 1c shows the arrangement of isolated pyroborate units, appearing as two parallel pseudoone-dimensional chains spiraling around the $2_{1}$ axis.

There is one crystallographically independent $\mathrm{Mn}$ atom which is coordinated by five oxygen atoms to form a square pyramid with four longer equatorial $\mathrm{Mn}-\mathrm{O}$ bonds and one short apical $\mathrm{Mn}-\mathrm{O}$ bond. Fig. $2 a$ shows two $\mathrm{Mn} 1 \mathrm{O}_{5}$ square pyramids sharing a common edge, $\mathrm{O} 2-\mathrm{O} 2(-x+1,-y,-z)$, to form an $\mathrm{Mn}_{2} \mathrm{O}_{8}$ unit. As shown in Fig. $3 a$, Mn atoms are connected to each other via oxygen atoms with a Mn1 $\cdots \mathrm{Mn} 1$ separation of 3.317 (2) $\AA$ and an $\mathrm{Mn} 1-\mathrm{O} 2-\mathrm{Mn} 1$ angle of $101.23(16)^{\circ}$. The neighboring $\mathrm{Mn}_{2} \mathrm{O}_{8}$ dimers share vertices through oxygen atom $\mathrm{O} 3$. The oxygen atom $\mathrm{O} 1$ in the $\mathrm{Mn}_{2} \mathrm{O}_{8}$ dimer is only corner-shared by the pyroborate group. The only unshared oxygen, $\mathrm{O} 4$, of the pyroborate group is pointing into the free space towards the neighboring slabs to form a bond with the barium atom. As shown in Fig. $3 b$, with respect to the pyroborate group, the $\mathrm{B}_{2} \mathrm{O}_{3}$ unit shares two corners with neighboring $\mathrm{MnO}_{5}$ square pyramids through $\mathrm{O} 1$ and $\mathrm{O} 2$ while the $\mathrm{B}_{10} \mathrm{O}_{3}$ unit corner-shares a common oxygen atom, $\mathrm{O} 3$, with two other $\mathrm{MnO}_{5}$ square pyramids. This arrangement facilitates the observed curvature which is necessary for the spiral framework found in the extended lattice (Fig. 1b). The unique arrangement of $\mathrm{B}_{2} \mathrm{O}_{5}$ groups around the $2_{1}$ screw axis provides an essential element allowing the spiral chain to propagate along the $b$ axis. It is well known that the interplanar angle of the $\mathrm{B}_{2} \mathrm{O}_{5}$ group is primarily dictated by packing effects and the nature of the associated cations in the given structure (Thompson et al., 1991). In addition to that, as previously noted, the greater deviations from coplanarity are observed in the arrangement of the $\mathrm{B}_{2} \mathrm{O}_{5}$ groups due to variation of the sizes of alkali metals in alkali metal $\mathrm{Nb}$ and Ta oxide pyroborates (Akella \& Keszler, 1995). Accordingly, the interplanar angle of the $\mathrm{B}_{2} \mathrm{O}_{5}$ group is likely to be determined by the associate coordination environment of the barium cations in the title compound. It should be noted that the connectivity of the $\mathrm{Mn}_{2} \mathrm{O}_{8}$ and $\mathrm{B}_{2} \mathrm{O}_{5}$ structure units would result in a 'dangling' framework unless it can be tightly held together by external bonds. The $\mathrm{Ba}^{2+}$ cations, in this case, reside in the spiral framework arranging in zigzag fashion to support and maintain the distance between neighboring $\left[\mathrm{MnB}_{2} \mathrm{O}_{5}\right]^{2-}$ slabs. Coincidentally, this wavy arrangement is critical for the spiral chain to propagate along the $b$ axis. The flexible $\left[\mathrm{MnB}_{2} \mathrm{O}_{5}\right]^{2-}$ framework revolves around $\mathrm{Ba}^{2+}$ cations, suggesting a template-like behavior.

The $\mathrm{MnO}_{5}$ units adopt bond lengths normally observed in the $\mathrm{Mn}^{\mathrm{II}}$ borates. The $\mathrm{Mn}^{2+}-\mathrm{O}$ bond lengths range from 2.082 (4) to 2.151 (4) $\AA$, comparable with $2.10 \AA$, the sum of the Shannon crystal radii (Shannon, 1976) for a five coordinated $\mathrm{Mn}^{2+}(0.89 \AA)$ and two-coordinated $\mathrm{O}^{2-}(1.21 \AA)$. The bond-valence-sum (BVS) calculations (Brese \& O'Keeffe, 1991) for $\mathrm{BaMnB}_{2} \mathrm{O}_{5}$ give a valence unit (v.u.) of 2.03 for the $\mathrm{Mn}^{2+}$ cation. Based on parameters for $\mathrm{B}^{3+}-\mathrm{O}$, bond-valence sums of 2.95 for $\mathrm{B}^{3+}$ and 2.95 for $\mathrm{B} 2^{3+}$ were calculated. The $\mathrm{Ba}-\mathrm{O}$ bond lengths are quite diverse, ranging from 2.707 (4) to 2.958 (4) $\AA$. The average $\mathrm{Ba}-\mathrm{O}$ bond length, $2.83 \AA$, however matches closely with $2.82 \AA$, the sum of the Shannon crystal radii for a nine coordinated $\mathrm{Ba}^{2+}(1.61 \AA)$ and twocoordinated $\mathrm{O}^{2-}(1.21 \AA)$. The $\mathrm{BVS}$ calculation for $\mathrm{Ba}^{2+}$ results in 2.08 v.u.

One of the interesting features of the title compound is that the structure can be alternatively viewed as a 'porous' 
framework as shown in Fig. $4 a$. The $\mathrm{B}_{2} \mathrm{O}_{5}$ units together with interconnected $\mathrm{Mn}_{2} \mathrm{O}_{8}$ dimers extend along the $b$ axis in a standing wave fashion, creating oval shape windows which also arrange in a zigzag fashion along the same direction. It is intriguing to notice that the two $\mathrm{B}_{2} \mathrm{O}_{5}$ groups along with the two $\mathrm{Mn}_{2} \mathrm{O}_{8}$ dimers and two $\mathrm{MnO}_{5}$ square pyramids create an empty cage (Fig. 4c,d). The polyhedral and ball-and-stick drawing (Fig. $4 b$ ) clearly shows the three-dimensional framework bearing large cavities. This unusual structural arrangement is conceivably attributed to the limitation of the size of the pyroborate unit that simultaneously tends to interconnect with barium cations and neighboring $\mathrm{Mn}_{2} \mathrm{O}_{8}$ dimers in a corner-shared fashion (Fig. $3 b$ ). As shown in Fig. $5 a$, the layered nature of the title compound is characterized by parallel $\left[\mathrm{MnB}_{2} \mathrm{O}_{5}\right]^{2-}$ slabs outlined by a dotted rectangle viewed along [010]. Fig. $5 b$ shows the ball-and-stick drawing of a portion of the layered manganese oxide network. Each $\mathrm{Mn}_{2} \mathrm{O}_{8}$ dimer shares vertices with four other $\mathrm{MnO}_{5}$ square pyramids through oxygen atoms to form these sheets. Within the extended $\mathrm{Mn}-\mathrm{O}$ sheet, the $\mathrm{MnO}_{5}$ square pyramids which share edges are separated from each other by 3.317 (2) $\AA$ (Mn1 ‥Mn1 distance) whereas those which share corners are separated by 3.435 (1) $\AA$. The distance between the Mn atoms of the adjacent sheets is 8.287 (2) $\AA$. Given the description of the local configuration of the manganese oxide polyhedra, their connectivity along the sheet, and the structural isolation of neighboring $\mathrm{Mn}-\mathrm{O}$ sheets from each other, one would suspect that the title compound offers opportunities for the study of spin exchange in a confined $\mathrm{Mn}-\mathrm{O}$ lattice. In theory, a periodic array of well-defined transition metal oxide lattices could provide a useful model for experimental and theoretical developments of magnetic and electronic interactions in transition metal oxides because of their simplified structures (Snyder et al., 2001).

The structure of $\mathrm{BaMnB}_{2} \mathrm{O}_{5}$ is somewhat related to that of triclinic $M_{2} \mathrm{~B}_{2} \mathrm{O}_{5}(M=\mathrm{Mn}$, Sarrat et al., 2005; Fe, Neumair \& Huppertz, 2009; Co, Rowsell et al., 2003) phases. The structures of $M_{2} \mathrm{~B}_{2} \mathrm{O}_{5}(M=\mathrm{Mn}, \mathrm{Fe}, \mathrm{Co})$ phases are based on structurally isolated $\left[M_{4} \mathrm{O}_{18}\right]$ tetramers, composed of four octahedra linked by three shared edges, connected through sharing four $\mathrm{O}-\mathrm{O}$ edges, into ribbons extending along (001) while the boron atoms hold the ribbons together forming $\mathrm{B}_{2} \mathrm{O}_{5}$ groups. These extended ribbons are parallel to each other and therefore these $M_{2} \mathrm{~B}_{2} \mathrm{O}_{5}$ phases have a quasi-one-dimensional structure in contrast to the two-dimensional $\mathrm{Mn}-\mathrm{O}$ lattice in the title compound. Magnetic properties have been widely studied for $\mathrm{Co}_{2} \mathrm{~B}_{2} \mathrm{O}_{5}$ (Kawano et al., 2010), $\mathrm{Fe}_{2} \mathrm{~B}_{2} \mathrm{O}_{5}$ (Kawano et al., 2009), and $\mathrm{Mn}_{2} \mathrm{~B}_{2} \mathrm{O}_{5}$ (Fernandes et al., 2003) to understand the low-dimensional interactions derived from the ribbon-like substructures in these compounds. The spin configuration based on the electron-density distribution has been proposed (Sarrat et al., 2005) for $\mathrm{Mn}_{2} \mathrm{~B}_{2} \mathrm{O}_{5}$ in which the distance between manganese atoms of adjacent ribbons are 4.526-6.272 $\AA$ and electron-density distributions were indicated in the regions between the ribbons. According to their model, all coplanar ribbons of $\mathrm{Mn}_{2} \mathrm{~B}_{2} \mathrm{O}_{5}$ are ferromagnetic; their antiferromagnetic behavior is derived from antiparallel
Table 1

Experimental details

\begin{tabular}{|c|c|}
\hline \multicolumn{2}{|l|}{ Crystal data } \\
\hline Chemical formula & $\mathrm{BaMnB}_{2} \mathrm{O}_{5}$ \\
\hline$M_{\mathrm{r}}$ & 293.90 \\
\hline Crystal system, space group & Monoclinic, $P 2_{1} / c$ \\
\hline Temperature (K) & 300 \\
\hline$a, b, c(\AA)$ & $\begin{array}{l}8.2868(17), 8.6570(17) \\
\quad 6.5263(13)\end{array}$ \\
\hline$\beta\left(^{\circ}\right)$ & $92.87(3)$ \\
\hline$V\left(\AA^{6}\right)$ & $467.60(16)$ \\
\hline$Z$ & 4 \\
\hline Radiation type & Мо $K \alpha$ \\
\hline$\mu\left(\mathrm{mm}^{-1}\right)$ & 10.99 \\
\hline Crystal size $(\mathrm{mm})$ & $0.17 \times 0.05 \times 0.02$ \\
\hline \multicolumn{2}{|l|}{ Data collection } \\
\hline Diffractometer & Rigaku AFC8S \\
\hline Absorption correction & $\begin{array}{l}\text { Multi-scan (REQAB; Rigaku, } \\
\text { 1998) }\end{array}$ \\
\hline$T_{\min }, T_{\max }$ & $0.518,0.808$ \\
\hline $\begin{array}{l}\text { No. of measured, independent and } \\
\text { observed }[I>2 \sigma(I)] \text { reflections }\end{array}$ & $3807,830,777$ \\
\hline$R_{\text {int }}$ & 0.052 \\
\hline$(\sin \theta / \lambda)_{\max }\left(\AA^{-1}\right)$ & 0.598 \\
\hline \multicolumn{2}{|l|}{ Refinement } \\
\hline$R\left[F^{2}>2 \sigma\left(F^{2}\right)\right], w R\left(F^{2}\right), S$ & $0.025,0.056,1.10$ \\
\hline No. of reflections & 830 \\
\hline No. of parameters & 83 \\
\hline$\Delta \rho_{\max }, \Delta \rho_{\min }\left(\mathrm{e} \AA^{-3}\right)$ & $0.82,-0.98$ \\
\hline
\end{tabular}

Computer programs: CrystalClear (Rigaku, 2006), SHELXT (Sheldrick, 2015a), SHELXL2014 (Sheldrick, 2015b), DIAMOND (Brandenburg, 1999) and publCIF (Westrip, 2010).

magnetic orientations between adjacent ribbons. In the title compound, the distance between manganese atoms within the sheets and adjacent sheets are $3.317(2)-3.435$ (1) $\AA$ and 8.287 (2) $\AA$, respectively. It is important to note that the $\mathrm{Ba}^{2+}$ cations reside in the gap between the two $\mathrm{Mn}-\mathrm{O}$ sheets. This, together with the greater separation between manganese atoms of adjacent sheets, leads us to believe that magnetic interactions that occur between $\mathrm{Mn}-\mathrm{O}$ sheets can be extremely weak and the dominant magnetic exchange should be between $\mathrm{Mn}^{2+}$ ions within the $\mathrm{Mn}-\mathrm{O}$ sheet. Judging from the interesting magnetic properties reported for $M_{2} \mathrm{~B}_{2} \mathrm{O}_{5}(M=$ $\mathrm{Mn}, \mathrm{Fe}, \mathrm{Co})$ compounds, we expect interesting magnetic phenomena from a systematic investigation of the magnetic susceptibility of $\mathrm{BaMnB}_{2} \mathrm{O}_{5}$.

\section{Synthesis and crystallization}

Light pink crystals of $\mathrm{BaMnB}_{2} \mathrm{O}_{5}$ were grown by employing a $\mathrm{CsCl} / \mathrm{RbCl}$ flux in a fused silica ampoule under vacuum. $\mathrm{MnO}$ (2.74 mmol, 99.999+\%, Alfa), $\mathrm{BaO}$ (1.37 mmol, 99.99+\%, Aldrich) and $\mathrm{B}_{2} \mathrm{O}_{3}$ (1.37 mmol, 99.98+\%, Aldrich) were mixed and ground with the flux (1:3 by weight) in a nitrogen-blanketed drybox. The resulting mixture was heated to $818 \mathrm{~K}$ at $1 \mathrm{~K} \mathrm{~min}^{-1}$, isothermed for two days, heated to $1023 \mathrm{~K}$ at $1 \mathrm{~K} \mathrm{~min}^{-1}$, isothermed for four days, then slowly cooled to $673 \mathrm{~K}$ at $0.1 \mathrm{~K} \mathrm{~min}^{-1}$ followed by furnace-cooling to room temperature. Prismatic crystals of $\mathrm{BaMnB}_{2} \mathrm{O}_{5}$ were retrieved upon washing off the solidified melt with deionized water. 


\section{Refinement}

Crystal data, data collection and structure refinement details are summarized in Table 1. The final Fourier difference synthesis showed the maximum residual electron density in the difference Fourier map, 0.82 e $\AA^{-3}$, located at $1.19 \AA$ from Ba1 and the minimum, $-0.98 \mathrm{e}^{-} \AA^{-3}$, at $0.92 \AA$ from Ba1.

\section{Acknowledgements}

The Division of Science at Governors State University is gratefully acknowledged for the continuous support. Special thanks are due to Dr Julien P. A. Makongo for his X-ray crystallography expertise.

\section{References}

Akella, A. \& Keszler, D. A. (1995). J. Solid State Chem. 120, 74-79. Berger, S. V. (1950). Acta Chem. Scand. 4, 1054-1065.

Brandenburg, K. (1999). DIAMOND. Crystal Impact GbR, Bonn, Germany.

Brese, N. E. \& O'Keeffe, M. (1991). Acta Cryst. B47, 192-197.

Busche, S. \& Bluhm, K. (1995). Z. Naturforsch. Teil B, 50, 1445-1449.

Callegari, A., Mazzi, F. \& Tadini, C. (2003). Eur. J. Miner. 15, 277-282.

Fernandes, J. C., Sarrat, F. S., Guimarães, R. B., Freitas, R. S., Continentino, M. A., Doriguetto, A. C., Mascarenhas, Y. P., Ellena, J., Castellano, E. E., Tholence, J. L., Dumas, J. \& Ghivelder, L. (2003). Phys. Rev. B, 67, 104413-1-104413-7.

Guo, G.-C., Cheng, W.-D., Chen, J.-T., Huang, J.-S. \& Zhang, Q.-E. (1995a). Acta Cryst. C51, 351-353.

Guo, G.-C., Cheng, W.-D., Chen, J.-T., Zhuang, H.-H., Huang, J.-S. \& Zhang, Q.-E. (1995b). Acta Cryst. C51, 2469-2471.

Heller, G. (1986). Top. Curr. Chem. 131, 39-98.
Hubner, K. H. (1969). Neues Jahrb. Mineral. Monatsh. pp. 335-343.

Kawano, T., Morito, H., Yamada, T., Onuma, T., Chichibu, S. F. \& Yamane, H. (2009). J. Solid State Chem. 182, 2004-2009.

Kawano, T., Morito, H. \& Yamane, H. (2010). Solid State Sci. 12, 1419-1421.

Lin, Q.-S., Cheng, W.-D., Chen, J.-T. \& Huang, J.-S. (1999a). Acta Cryst. C55, 4-6.

Lin, Q.-S., Cheng, W.-D., Chen, J.-T. \& Huang, J.-S. (1999b). J. Solid State Chem. 144, 30-34.

Neumair, S. C. \& Huppertz, H. (2009). Z. Naturforsch. Teil B, 64, 491498.

Rigaku (1998). REQAB. Rigaku Corporation, Tokyo, Japan.

Rigaku (2006). CrystalClear. Rigaku Corporation, Tokyo, Japan.

Rowsell, J. L. C., Taylor, N. J. \& Nazar, L. F. (2003). J. Solid State Chem. 174, 189-197.

Sarrat, F. S., Guimarães, R. B., Continentino, M. A., Fernandes, J. C., Doriguetto, A. C. \& Ellena, J. (2005). Phys. Rev. B, 71, 224413-1224413-6.

Shannon, R. D. (1976). Acta Cryst. A32, 751-767.

Sheldrick, G. M. (2015a). Acta Cryst. A71, 3-8.

Sheldrick, G. M. (2015b). Acta Cryst. C71, 3-8.

Simonov, M. A., Egorov-Tismenko, Yu. K., Yamnova, N. A., Belokoneva, E. L. \& Belov, N. V. (1980). Dokl. Akad. Nauk SSSR, 251, 1125-1128.

Smith, R. W. \& Keszler, D. A. (1997). J. Solid State Chem. 129, 184188.

Snyder, J., Slusky, J. S., Cava, R. J. \& Schiffer, P. (2001). Nature, 413, 48-51.

Thompson, P. D., Huang, J., Smith, R. W. \& Keszler, D. A. (1991). J. Solid State Chem. 95, 126-135.

Utzolino, A. \& Bluhm, K. (1996). Z. Naturforsch. Teil B, 51, 912-916.

Weil, M. (2003). Acta Cryst. E59, i95-i97.

Westrip, S. P. (2010). J. Appl. Cryst. 43, 920-925.

Yakubovich, O. V., Yamnova, N. A., Shchedrin, B. M., Simonov, M. A. \& Belov, N. V. (1976). Dokl. Akad. Nauk SSSR, 228, 842-845.

Zobetz, E. (1982). Z. Kristallogr. 160, 81-92. 


\section{supporting information}

Acta Cryst. (2016). E72, 1315-1320 [https://doi.org/10.1107/S2056989016013074]

Crystal structure of $\mathrm{BaMnB}_{2} \mathrm{O}_{5}$ containing structurally isolated manganese oxide sheets

Elizabeth M. Maschmeyer, Liurukara D. Sanjeewa and Kulugammana G. S. Ranmohotti

Computing details

Data collection: CrystalClear (Rigaku, 2006); cell refinement: CrystalClear (Rigaku, 2006); data reduction: CrystalClear (Rigaku, 2006); program(s) used to solve structure: SHELXT (Sheldrick, 2015a); program(s) used to refine structure: SHELXL2014 (Sheldrick, 2015b); molecular graphics: DIAMOND (Brandenburg, 1999); software used to prepare material for publication: publCIF (Westrip, 2010).

Barium manganese(II) pyroborate

Crystal data

$\mathrm{BaMnB}_{2} \mathrm{O}_{5}$

$M_{r}=293.90$

Monoclinic, $P 2_{1} / c$

$a=8.2868(17) \AA$

$b=8.6570(17) \AA$

$c=6.5263(13) \AA$

$\beta=92.87(3)^{\circ}$

$V=467.60(16) \AA^{3}$

$Z=4$

$F(000)=524$

$D_{\mathrm{x}}=4.175 \mathrm{Mg} \mathrm{m}^{-3}$

Mo $K \alpha$ radiation, $\lambda=0.71073 \AA$

Cell parameters from 3139 reflections

$\theta=3.1-29.6^{\circ}$

$\mu=10.99 \mathrm{~mm}^{-1}$

$T=300 \mathrm{~K}$

Prismatic, pink

$0.17 \times 0.05 \times 0.02 \mathrm{~mm}$

\section{Data collection}

Rigaku AFC8S diffractometer

Radiation source: fine-focus sealed tube $\omega$ scans

Absorption correction: multi-scan (REQAB; Rigaku, 1998)

$T_{\min }=0.518, T_{\max }=0.808$

3807 measured reflections

830 independent reflections

777 reflections with $I>2 \sigma(I)$

$R_{\text {int }}=0.052$

$\theta_{\text {max }}=25.2^{\circ}, \theta_{\min }=3.4^{\circ}$

$h=-9 \rightarrow 9$

$k=-10 \rightarrow 10$

$l=-7 \rightarrow 7$

1 standard reflections every 1 reflections

Refinement

Refinement on $F^{2}$

Least-squares matrix: full

$R\left[F^{2}>2 \sigma\left(F^{2}\right)\right]=0.025$

$w R\left(F^{2}\right)=0.056$

$S=1.10$

830 reflections

83 parameters

0 restraints

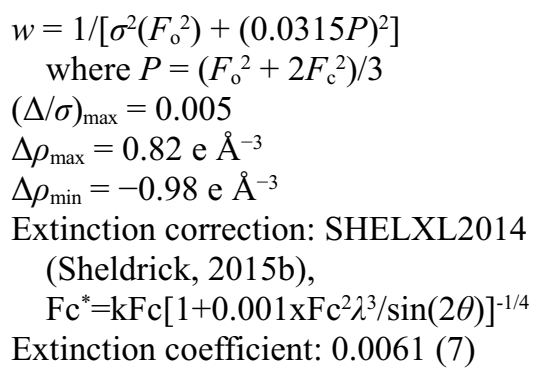




\section{Special details}

Geometry. All esds (except the esd in the dihedral angle between two 1.s. planes) are estimated using the full covariance matrix. The cell esds are taken into account individually in the estimation of esds in distances, angles and torsion angles; correlations between esds in cell parameters are only used when they are defined by crystal symmetry. An approximate (isotropic) treatment of cell esds is used for estimating esds involving l.s. planes.

Fractional atomic coordinates and isotropic or equivalent isotropic displacement parameters $\left(\AA^{2}\right)$

\begin{tabular}{lllll}
\hline & $x$ & $y$ & $z$ & $U_{\text {iso }} * / U_{\text {eq }}$ \\
\hline Ba1 & $0.14891(4)$ & $0.07969(4)$ & $0.22488(5)$ & $0.00932(16)$ \\
Mn1 & $0.53148(10)$ & $0.18805(10)$ & $0.02929(12)$ & $0.0087(2)$ \\
B1 & $0.1784(8)$ & $-0.2828(7)$ & $0.1447(10)$ & $0.0100(13)$ \\
B2 & $0.2960(8)$ & $0.4492(7)$ & $0.1980(10)$ & $0.0115(13)$ \\
O1 & $0.3314(5)$ & $0.3308(4)$ & $0.0723(6)$ & $0.0133(9)$ \\
O2 & $0.3587(5)$ & $0.0300(4)$ & $-0.1080(6)$ & $0.0126(9)$ \\
O3 & $0.3228(5)$ & $-0.2185(4)$ & $0.2184(6)$ & $0.0106(8)$ \\
O4 & $0.0457(5)$ & $-0.2018(4)$ & $0.0939(6)$ & $0.0110(8)$ \\
O5 & $-0.1725(5)$ & $0.0536(4)$ & $0.3763(6)$ & $0.0109(8)$ \\
\hline
\end{tabular}

Atomic displacement parameters $\left(\AA^{2}\right)$

\begin{tabular}{lllllll}
\hline & $U^{11}$ & $U^{22}$ & $U^{33}$ & $U^{12}$ & $U^{13}$ & $U^{23}$ \\
\hline Ba1 & $0.0103(2)$ & $0.0088(2)$ & $0.0088(2)$ & $0.00002(12)$ & $-0.00031(13)$ & $-0.00026(13)$ \\
Mn1 & $0.0094(5)$ & $0.0080(4)$ & $0.0086(5)$ & $0.0000(3)$ & $-0.0006(3)$ & $-0.0001(3)$ \\
B1 & $0.006(3)$ & $0.013(3)$ & $0.011(3)$ & $-0.002(3)$ & $0.000(2)$ & $0.002(3)$ \\
B2 & $0.010(3)$ & $0.011(3)$ & $0.014(3)$ & $0.005(3)$ & $0.000(3)$ & $-0.003(3)$ \\
O1 & $0.012(2)$ & $0.015(2)$ & $0.013(2)$ & $0.0056(17)$ & $-0.0030(17)$ & $-0.0054(17)$ \\
O2 & $0.017(2)$ & $0.0073(18)$ & $0.012(2)$ & $-0.0008(16)$ & $-0.0055(17)$ & $-0.0004(16)$ \\
O3 & $0.0108(19)$ & $0.0109(19)$ & $0.010(2)$ & $-0.0023(16)$ & $-0.0002(16)$ & $0.0011(16)$ \\
O4 & $0.012(2)$ & $0.009(2)$ & $0.012(2)$ & $0.0033(16)$ & $0.0004(16)$ & $-0.0018(16)$ \\
O5 & $0.013(2)$ & $0.0075(19)$ & $0.012(2)$ & $0.0010(16)$ & $-0.0036(16)$ & $0.0006(16)$ \\
\hline
\end{tabular}

Geometric parameters $\left(\AA,{ }^{\circ}\right)$

\begin{tabular}{llll}
\hline $\mathrm{Ba} 1-\mathrm{O} 4$ & $2.707(4)$ & $\mathrm{Mn} 1-\mathrm{O} 1$ & $2.098(4)$ \\
$\mathrm{Ba} 1-\mathrm{O} 1^{\mathrm{i}}$ & $2.772(4)$ & $\mathrm{Mn} 1-\mathrm{O} 2$ & $2.144(4)$ \\
$\mathrm{Ba} 1-\mathrm{O} 4^{\mathrm{ii}}$ & $2.777(4)$ & $\mathrm{Mn} 1-\mathrm{O} 2^{\mathrm{v}}$ & $2.147(4)$ \\
$\mathrm{Ba} 1-\mathrm{O} 4^{\mathrm{iii}}$ & $2.787(4)$ & $\mathrm{Mn} 1-\mathrm{O} 3^{\mathrm{vi}}$ & $2.151(4)$ \\
$\mathrm{Ba} 1-\mathrm{O} 5^{\mathrm{iv}}$ & $2.845(4)$ & $\mathrm{B} 1-\mathrm{O} 4$ & $1.332(8)$ \\
$\mathrm{Ba} 1-\mathrm{O} 1$ & $2.855(4)$ & $\mathrm{B} 1-\mathrm{O} 3$ & $1.384(7)$ \\
$\mathrm{Ba} 1-\mathrm{O} 2$ & $2.882(4)$ & $\mathrm{B} 1-\mathrm{O} 5^{\mathrm{vii}}$ & $1.423(7)$ \\
$\mathrm{Ba} 1-\mathrm{O} 5$ & $2.896(4)$ & $\mathrm{B} 2-\mathrm{O} 1$ & $1.354(7)$ \\
$\mathrm{Ba} 1-\mathrm{O} 3$ & $2.958(4)$ & $\mathrm{B} 2-\mathrm{O} 2^{\mathrm{i}}$ & $1.357(8)$ \\
$\mathrm{Mn} 1-\mathrm{O} 3^{\mathrm{v}}$ & $2.082(4)$ & $\mathrm{B} 2-\mathrm{O} 5^{\mathrm{iii}}$ & $1.432(7)$ \\
& & & \\
$\mathrm{O} 4-\mathrm{Ba} 1-\mathrm{O} 1^{\mathrm{i}}$ & $131.36(11)$ & $\mathrm{O} 1-\mathrm{Mn} 1-\mathrm{O}^{\mathrm{v}}$ & $144.52(16)$ \\
$\mathrm{O} 4-\mathrm{Ba} 1-\mathrm{O} 4^{\mathrm{ii}}$ & $86.77(11)$ & $\mathrm{O} 2-\mathrm{Mn} 1-2^{\mathrm{v}}$ & $102.77(16)$ \\
$\mathrm{O} 1^{\mathrm{i}}-\mathrm{Ba} 1-\mathrm{O} 4^{\mathrm{ii}}$ & $141.16(11)$ & $\mathrm{O} 3^{\mathrm{v}}-\mathrm{Mn} 1-\mathrm{O}^{\mathrm{vi}}$ &
\end{tabular}




\begin{tabular}{|c|c|c|c|}
\hline $\mathrm{O} 4-\mathrm{Ba} 1-\mathrm{O} 4^{\mathrm{iii}}$ & $124.37(5)$ & $\mathrm{O} 1-\mathrm{Mn} 1-\mathrm{O}^{\mathrm{vi}}$ & $95.36(15)$ \\
\hline 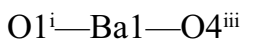 & $76.50(12)$ & $\mathrm{O} 2-\mathrm{Mn} 1-\mathrm{O}^{\mathrm{vi}}$ & $153.85(15)$ \\
\hline 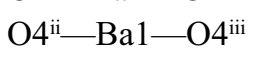 & $74.51(8)$ & $\mathrm{O} 2^{\mathrm{v}}-\mathrm{Mn} 1-\mathrm{O}^{\mathrm{vi}}$ & $86.12(14)$ \\
\hline $\mathrm{O} 4-\mathrm{Ba} 1-\mathrm{O} 5^{\mathrm{iv}}$ & $85.98(11)$ & $\mathrm{O} 1-\mathrm{B} 2-\mathrm{O} 2^{\mathrm{i}}$ & $125.6(5)$ \\
\hline $\mathrm{O} 1^{\mathrm{i}}-\mathrm{Ba} 1-\mathrm{O}^{\mathrm{iv}}$ & $49.87(11)$ & $\mathrm{O} 1-\mathrm{B} 2-\mathrm{O} 5^{\mathrm{iii}}$ & $116.5(5)$ \\
\hline $\mathrm{O} 4^{\mathrm{ii}}-\mathrm{Ba} 1-\mathrm{O} 5^{\mathrm{iv}}$ & $148.29(11)$ & $\mathrm{O} 2^{\mathrm{i}}-\mathrm{B} 2-\mathrm{O}^{\mathrm{iii}}$ & $117.8(5)$ \\
\hline $\mathrm{O} 4^{\mathrm{iii}}-\mathrm{Ba} 1-\mathrm{O}^{\mathrm{iv}}$ & $84.37(11)$ & $\mathrm{B} 2-\mathrm{O} 1-\mathrm{Mn} 1$ & $136.3(4)$ \\
\hline $\mathrm{O} 4-\mathrm{Ba} 1-\mathrm{O} 1$ & $137.70(12)$ & $\mathrm{B} 2-\mathrm{O} 1-\mathrm{Ba} 1^{\mathrm{viii}}$ & $99.1(3)$ \\
\hline $\mathrm{O} 1-\mathrm{i}-\mathrm{Ba} 1-\mathrm{O} 1$ & $78.21(9)$ & $\mathrm{Mn} 1-\mathrm{O} 1-\mathrm{Ba}^{\mathrm{viii}}$ & $117.24(16)$ \\
\hline 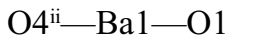 & $75.33(12)$ & $\mathrm{B} 2-\mathrm{O} 1-\mathrm{Ba} 1$ & 103.3 \\
\hline 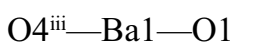 & $87.65(11)$ & $\mathrm{Mn} 1-\mathrm{O} 1-\mathrm{Ba} 1$ & $91.97(13)$ \\
\hline $\mathrm{O}^{5 \mathrm{iv}}-\mathrm{Ba} 1-\mathrm{O} 1$ & $127.91(11)$ & 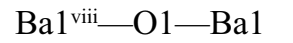 & $102.80(13)$ \\
\hline $\mathrm{O} 4-\mathrm{Ba} 1-\mathrm{O} 2$ & $79.67(11)$ & 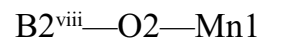 & $121.5(4)$ \\
\hline $\mathrm{O} 1-\mathrm{B} 1-\mathrm{O} 2$ & $109.48(11)$ & $\mathrm{B} 2^{\mathrm{viii}}-\mathrm{O} 2-\mathrm{Mn}^{\mathrm{v}}$ & $118.6(4)$ \\
\hline $\mathrm{O} 4^{\mathrm{ii}}-\mathrm{Ba} 1-\mathrm{O} 2$ & $80.88(11)$ & $\mathrm{Mn} 1-\mathrm{O} 2-\mathrm{Mn}^{\mathrm{v}}$ & $101.23(16)$ \\
\hline $\mathrm{O} 44^{\mathrm{iii}}-\mathrm{Ba} 1-\mathrm{O} 2$ & $143.59(11)$ & $\mathrm{B} 2^{\mathrm{viii}}-\mathrm{O} 2-\mathrm{Ba} 1$ & $117.8(4)$ \\
\hline $\mathrm{O}^{\mathrm{iv}}-\mathrm{Ba} 1-\mathrm{O} 2$ & $127.79(11)$ & $\mathrm{Mn} 1-\mathrm{O} 2-\mathrm{Ba} 1$ & $90.29(13)$ \\
\hline $\mathrm{O} 1-\mathrm{Ba} 1-\mathrm{O} 2$ & $60.05(11)$ & $\mathrm{Mn} 1^{\mathrm{v}}-\mathrm{O} 2-\mathrm{Ba} 1$ & $102.44(14)$ \\
\hline $\mathrm{O} 4-\mathrm{Ba} 1-\mathrm{O} 5$ & $75.88(11)$ & $\mathrm{B} 1-\mathrm{O} 3-\mathrm{Mn} 1^{\mathrm{v}}$ & $107.8(4)$ \\
\hline $\mathrm{O} 1{ }^{\mathrm{i}}-\mathrm{Ba} 1-\mathrm{O} 5$ & $102.48(11)$ & $\mathrm{B} 1-\mathrm{O} 3-\mathrm{Mn} 1^{\mathrm{ix}}$ & $123.9(3)$ \\
\hline $\mathrm{O} 4^{\mathrm{ii}}-\mathrm{Ba} 1-\mathrm{O} 5$ & $77.04(12)$ & $\mathrm{Mn} 1^{\mathrm{v}}-\mathrm{O} 3-\mathrm{Mn} 1^{\mathrm{ix}}$ & $108.48(17)$ \\
\hline $\mathrm{O} 4^{\mathrm{iii}-\mathrm{Ba} 1-\mathrm{O} 5}$ & $49.20(11)$ & $\mathrm{B} 1-\mathrm{O} 3-\mathrm{Ba} 1$ & $86.7(3)$ \\
\hline $\mathrm{O}^{\mathrm{iv}}-\mathrm{Ba} 1-\mathrm{O} 5$ & $71.25(13)$ & $\mathrm{Mn} 1^{\mathrm{v}}-\mathrm{O} 3-\mathrm{Ba} 1$ & $101.68(14)$ \\
\hline $\mathrm{O} 1-\mathrm{Ba} 1-\mathrm{O} 5$ & $133.67(10)$ & $\mathrm{Mn} 1^{\mathrm{ix}}-\mathrm{O} 3-\mathrm{Ba} 1$ & $124.92(15)$ \\
\hline $\mathrm{O} 2-\mathrm{Ba} 1-\mathrm{O} 5$ & $147.72(11)$ & $\mathrm{B} 1-\mathrm{O} 4-\mathrm{Ba} 1$ & $98.7(3)$ \\
\hline $\mathrm{O} 4-\mathrm{Ba} 1-\mathrm{O} 3$ & $49.93(11)$ & $\mathrm{B} 1-\mathrm{O} 4-\mathrm{Ba} 1^{\mathrm{ii}}$ & $145.9(4)$ \\
\hline 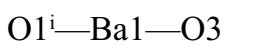 & $90.55(11)$ & $\mathrm{Ba} 1-\mathrm{O} 4-\mathrm{Ba}^{\mathrm{ii}}$ & $93.23(11)$ \\
\hline $\mathrm{O} 4^{\mathrm{ii}}-\mathrm{Ba} 1-\mathrm{O} 3$ & $125.91(11)$ & $\mathrm{B} 1-\mathrm{O} 4-\mathrm{Ba}^{\mathrm{vii}}$ & $91.4(3)$ \\
\hline 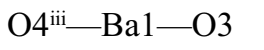 & $153.01(10)$ & $\mathrm{Ba} 1-\mathrm{O} 4-\mathrm{Ba}^{\mathrm{vii}}$ & $131.11(15)$ \\
\hline $\mathrm{O}^{\mathrm{iv}}-\mathrm{Ba} 1-\mathrm{O} 3$ & $69.38(11)$ & $\mathrm{Ba} 1^{\mathrm{ii}}-\mathrm{O} 4-\mathrm{Ba}^{\mathrm{vii}}$ & $104.46(13)$ \\
\hline $\mathrm{O} 1-\mathrm{Ba} 1-\mathrm{O} 3$ & $113.11(11)$ & 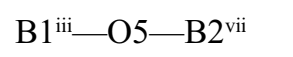 & $125.1(5)$ \\
\hline $\mathrm{O} 2-\mathrm{Ba} 1-\mathrm{O} 3$ & $63.01(10)$ & 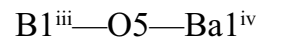 & $119.5(3)$ \\
\hline $\mathrm{O} 5-\mathrm{Ba} 1-\mathrm{O} 3$ & $113.20(11)$ & $\mathrm{B} 2^{\mathrm{vii}}-\mathrm{O} 5-\mathrm{Ba} 1^{\mathrm{iv}}$ & $93.9(3)$ \\
\hline $\mathrm{O}^{\mathrm{v}}-\mathrm{Mn} 1-\mathrm{O} 1$ & $121.48(15)$ & 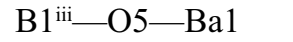 & $85.3(3)$ \\
\hline $\mathrm{O}^{\mathrm{v}}-\mathrm{Mn} 1-\mathrm{O} 2$ & $99.07(15)$ & $\mathrm{B} 2^{\mathrm{vii}}-\mathrm{O} 5-\mathrm{Ba} 1$ & $126.0(3)$ \\
\hline $\mathrm{O} 1-\mathrm{Mn} 1-\mathrm{O} 2$ & $85.17(16)$ & $\mathrm{Ba} 1^{\mathrm{iv}}-\mathrm{O} 5-\mathrm{Ba} 1$ & $108.75(13)$ \\
\hline $\mathrm{O}^{\mathrm{v}}-\mathrm{Mn} 1-\mathrm{O}^{2 \mathrm{v}}$ & $92.39(15)$ & & \\
\hline
\end{tabular}

Symmetry codes: (i) $x,-y+1 / 2, z+1 / 2$; (ii) $-x,-y,-z$; (iii) $-x, y+1 / 2,-z+1 / 2$; (iv) $-x,-y,-z+1$; (v) $-x+1,-y,-z$; (vi) $-x+1, y+1 / 2,-z+1 / 2$; (vii) $-x, y-1 / 2$, $-z+1 / 2$; (viii) $x,-y+1 / 2, z-1 / 2$; (ix) $-x+1, y-1 / 2,-z+1 / 2$. 